International

\section{Archives of Allergy and Immunology}

\section{Erratum}

Int Arch Allergy Immunol 2020;181:732

DOI: $10.1159 / 000508814$

In the article by Lin et al. entitled "Efficacy of Budesonide Nasal Spray on Neutrophilic Chronic Rhinosinusitis with Nasal Polyps: A Combined Clinical and Experimental Study" [Int Arch Allergy Immunol. 2020;181:551-562, DOI 10.1159/000507395], Figure 5a needs to be corrected. The correct figure is shown below. The authors would like to apologize for any inconvenience caused.

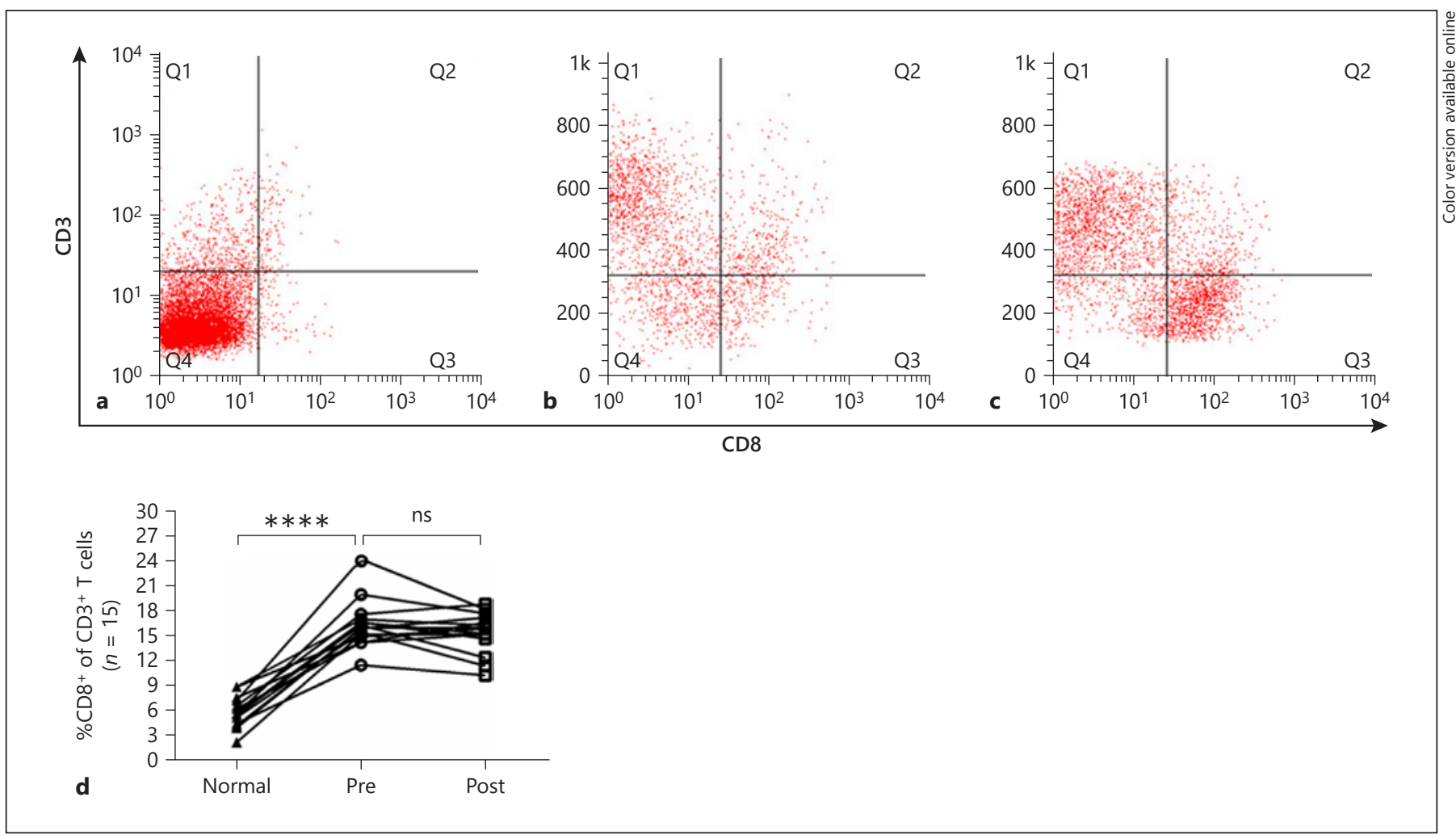

Fig. 5. Comparisons of $\mathrm{CD}^{+} \mathrm{CD}^{+} \mathrm{T}$ cells. a Flow cytometry analysis of $\mathrm{CD} 8^{+} \mathrm{T}$ cells in total $\mathrm{CD} 3^{+} \mathrm{T}$ cells in normal mucosa. b Flow cytometry analysis of $\mathrm{CD}^{+} \mathrm{T}$ cells in total $\mathrm{CD}^{+} \mathrm{T}$ cells in NPs of pretreatment. c Flow cytometry analysis of $\mathrm{CD}^{+} \mathrm{T}$ cells in total $\mathrm{CD} 3^{+} \mathrm{T}$ cells in NPs of posttreatment. $\mathbf{d}$ Comparisons of percentage of $\mathrm{CD}^{+} \mathrm{T}$ cells in total $\mathrm{CD}^{+} \mathrm{T}$ cells. Q1 quadrant, $\mathrm{CD} 3^{+} \mathrm{CD} 8^{-}$staining; 22 quadrant, $\mathrm{CD} 3^{+} \mathrm{CD} 8^{+}$staining; Q3 quadrant, $\mathrm{CD}^{-} \mathrm{CD}^{+}$staining; Q4 quadrant, $\mathrm{CD}^{-}{ }^{-} \mathrm{CD} 8^{-}$staining; Normal, normal mucosa; NPs, nasal polyps; SEM, standard error of the mean; ns, not significant; Pre, pretreatment; Post, posttreatment. The values shown are expressed as mean \pm SEM. ${ }^{* * * *} \mathrm{p}<0.0001$. 